\title{
How is global climate policy interpreted on the ground? Insights from the analysis of local discourses about forest management and REDD+ in Indonesia
}

\author{
$\underline{\text { Sarah Milne }}^{1}$, Mary Milne $^{1}$, Fitri Nurfatriani $^{2}$ and $\underline{\text { Luca Tacconi }}^{1}$
}

\begin{abstract}
The implementation of "reducing emissions from deforestation and forest degradation" (REDD+) will inevitably be affected by local social and political dynamics, with the potential for success depending significantly on cooperation from a range of stakeholders at the subnational level. Building on recent critical research on REDD+, we look at how global policy is interpreted locally by actors who are likely to be involved in REDD+ implementation. We do this by examining local stakeholder perceptions of REDD+ and forest management in two contrasting provinces of Indonesia, Riau and Papua, where deforestation rates are high and low, respectively. Using data collected from stakeholder workshops, we conduct a discourse analysis that reveals how subnational actors perceive and position themselves around REDD+ and forest governance. The results reveal six discourses common to both case-study provinces, which variously conflict and converge as they are employed by different actors. Seen together, these discourses provide critical insights into the subnational policy environment, which is largely a product of Indonesia's underlying land and forest politics, and they indicate in turn how REDD+ in practice is likely to be interpreted and reconstituted at the local level. A key finding is that local discourses can be grouped around two divergent positions on REDD+: one that supports forest exploitation and sees limited prospects in forest carbon, and one that embraces sustainable forest management and expresses conditional support for REDD+ subject to benefit-sharing and property arrangements. REDD+ practitioners will therefore need to craft policies and project processes that account for these discursive dynamics.
\end{abstract}

Key Words: deforestation; discourse; environmental politics; Indonesia; REDD+

\section{INTRODUCTION}

The idea of reducing emissions from deforestation and forest degradation (REDD+) has generated significant interest and investment in forest governance. Part of the global climate agreement signed in Paris in December 2015, REDD+ aims to provide incentives to developing countries to conserve and sustainably manage their forests for climate change mitigation purposes (UNFCCC 2015). Investments in REDD+ "readiness" and early implementation have already exceeded \$2 billion USD globally, with further financial flows expected as Paris commitments materialize (Silva-Chávez 2015) and as carbon markets mature (Climate Funds Update, http://www. climatefundsupdate.org/). Given the potential influence of REDD+, concerns have been expressed about its effects on forests, governance conditions, and local communities (Phelps et al. 2010, Eilenberg 2015). Furthermore, empirical work on early REDD+ projects suggests that there are implementation challenges and ambiguous local outcomes (e.g., Beymer-Farris and Bassett 2012, Howell 2015, Mahanty et al. 2015).

In this context, our motivation is to explore why there have been difficulties with REDD+ in practice. To do this, we focus on the subnational REDD+ policy environment in Indonesia, a line of inquiry that extends and complements recent social science research on wider REDD+ policy processes (see, for example, special features in Ecology and Society [Brockhaus et al. 2014a] and Asia Pacific Viewpoint [McGregor et al. 2015]). Importantly, this research points to the interplay between domestic political dynamics, evolving policy discourses, and REDD+ outcomes on the ground (McGregor 2010, Brockhaus et al. 2014b, Luttrell et al. 2014). It also analyzes how REDD+ in practice may be affected by the perceptions of local stakeholders who are either involved in or affected by REDD+ (Purnomo et al. 2012, Entenmann and Schmitt 2013, Mulyani and Jepson 2013). Overall, this work highlights the need for REDD+ to respond to diverse interests and values if it is to gain traction in practice, a problem that is just as pressing as the technical aspects of REDD+ such as carbon and financial incentives calculations.

The endeavor of aligning interests or forming alliances around REDD+ is fraught by the complexity of stakeholder or actor viewpoints on forest governance (we use the terms actor and stakeholder interchangeably to indicate an individual, organization, or group; see Grimble and Chan 1995). Here, we approach this problem empirically by focusing on the various discourses used by local and subnational actors in the context of REDD+ and forest management in two Indonesian provinces. Our study is grounded in the view that policy implementation emerges from deals forged in policy networks (Keeley and Scoones 1999), akin to "discourse coalitions" that can form between diverse actors in a given policy environment (Hajer 1995). Our intention is therefore to illustrate how the global policy idea of REDD+ is interpreted and reformulated at the local level, a realm that is highly heterogeneous and politically charged, but which is the "make it or break it" space for REDD+ in practice. In other words, we contend that REDD+ realization will ultimately depend on buy-in from local actors that are involved in forestry and land use, i.e., those who administer, use, and have rights to 
forested land, including district and provincial governments, concession holders, and communities in forested areas. Our study therefore investigates: (1) the perceptions and discourses of these local actors with respect to REDD+ and forest management, and (2) what our findings suggest for REDD+ implementation in terms of potential alliances or blockages among actors.

Understanding the local policy environment in this way is vital because, as scholars of complex social-ecological systems indicate, wicked problems such as deforestation cannot simply be solved by "getting the policy right" (e.g., Adger et al. 2003, Mosse 2004). Rather, it is necessary to consider how and why policy implementation may get blocked or go awry. For example, anthropological perspectives on environment and development projects reveal how gaps between good intentions and practical outcomes frequently arise when there are cross-scalar or crosscultural differences in actor perspectives (Leach and Mearns 1996, West 2006, Li 2007). In this light, our study focuses on how local actors' discourses are likely to interact with REDD+ design and implementation. Methodologically, we achieve this by combining discourse analysis and stakeholder analysis, which is a key innovation. We therefore provide a unique overview of the full range of subnational REDD+ stakeholders, their diverse, conflicting or similar views, and how eliciting those views is fundamental to understanding REDD+ policy prospects on the ground.

The significance of Indonesia as the setting for this study cannot be overlooked. This country has one of the highest deforestation rates in the world (FAO 2010), and it is one of the biggest carbon emitters globally, with approximately three-quarters of its emissions arising from land-use change and deforestation (DNPI $2010 a$ ). For these reasons, Indonesia has received unprecedented international investment in REDD + and other climate interventions. Indeed, by 2009, Indonesia boasted the largest number of REDD+ pilot activities globally (WertzKanounnikoff and Kongphan-Apirak 2009), a set of circumstances that prompted the Indonesian government to commit to cutting emissions by $26 \%$ against business-as-usual by 2020 and by $41 \%$ with additional support from the international community (Yudhoyono 2009). This move led to a bilateral agreement with Norway for REDD+, which included a moratorium on logging and forest conversion, among other things. However, several years on, the Norwegian money remains underspent, and the effectiveness of Indonesia's logging ban is in question (Coates 2012, Lang 2013). These frustrations derive particularly from Indonesia's political context, which points to a critical need to "build domestic constituencies" in support of forest reform (Luttrell et al. 2014) and to acknowledge how power relations influence policy implementation (Eilenberg 2015). Our analysis of subnational discourses around REDD+ should contribute to this task, particularly from a methodological point of view. For specific policy inputs, we recommend that our approach be replicated in more provinces to detect potential variation in local discourses between places and over time.

We next outline how discourse plays a fundamental role in the elaboration of environmental policies such as REDD+. We then describe our study design and methods, which involved analysis of discursive material gathered at two stakeholder workshops in Riau and Papua provinces. With our results, we explore the contours of the local discourses we identified around forest management and REDD + . We then discuss how these discursive dynamics could affect REDD+ implementation in Indonesia and elsewhere.

\section{THEORETICAL FRAMEWORK}

Environmental policy making is widely recognized as a contested and political process in which multiple perspectives on environmental problems and their potential solutions come into play (Hajer 1995, Leach and Mearns 1996, Dryzek 1997, Keeley and Scoones 1999). A key issue is that policy makers frequently pay insufficient attention to the conflicting interests and views of different local actors or stakeholders during policy formulation (Grimble and Chan 1995, Neumann 2005). Environmental projects may therefore achieve better results if policy makers can attend to the various ways that stakeholders conceptualize environmental issues in the first place (Adams et al. 2003). Furthermore, by understanding what stakeholders may lose or gain through proposed changes to natural resource management, policy processes can mitigate against potential blockages or negative impacts (Grimble and Chan 1995).

One way to examine competing ideas in the policy process, and associated power dynamics between actors, is to employ the concept of discourse. A discourse is a "shared meaning of a phenomenon," reflecting claims made by certain actors, rather than objective knowledge per se (Adger et al. 2001). Following the definition of Hajer (1995), discourses form the context in which phenomena are understood; they frame problems in particular ways and distinguish some aspects of a situation over others. Discourses can therefore be identified in proponents' assumptions and logics, and in the way they advance their agendas through particular narratives (Roe 1991) or storylines (Hajer 1995). Thus, discourse analysis reveals how multiple viewpoints on environmental problem solving can exist simultaneously, as seen in the oft-observed discursive struggles of scientists, activists, local communities, and politicians (Hajer 1995, Fairhead and Leach 2003, Gray et al. 2007).

Some analysis of REDD+ policy discourses and stakeholder perspectives has already been conducted. For example, research into national-level discourses on climate change adaptation and mitigation in the Congo basin revealed a variety of discursive framings or positions on REDD+ policy (Brown et al. 2011, Somorin et al. 2012). Similarly, in the Peruvian Amazon, Evans et al. (2014) examined local community perspectives on REDD+, which they contrasted with national and global policy contructs; and Entenmann and Schmitt (2013) identified diverse actor perceptions of the relationship between REDD+ and biodiveristy values. Although signaling the importance of discourse, none of these studies engages with the full range of subnational REDD+ stakeholders and how their discourses may reflect policy challenges, as we do here.

To identify relevant actors and their voices, we draw from the technique of stakeholder analysis, which has long been used to understand resource conflicts in environmental projects (de Lopez 2001, Hjortsø et al. 2005, Mushove and Vogel 2005). A stakeholder may be defined as any individual or group either directly involved in, or affected by, the exploitation or management of a given resource, in this case, forests (following Grimble and Chan 1995). Formal stakeholder analysis has been 
Table 1. Stakeholder groups and numbers of participants involved in the workshops.

\begin{tabular}{|c|c|c|c|c|c|c|}
\hline \multirow[b]{2}{*}{ Workshop } & \multicolumn{6}{|c|}{ Stakeholder group } \\
\hline & $\begin{array}{c}\text { Community and social } \\
\text { NGOs }^{\dagger}\end{array}$ & $\begin{array}{c}\text { Companies and } \\
\text { business }\end{array}$ & District government & $\begin{array}{l}\text { Provincial } \\
\text { government }\end{array}$ & $\begin{array}{c}\text { Researchers and } \\
\text { environmental NGOs }\end{array}$ & Total \\
\hline Riau & 6 & 7 & 10 & 5 & 5 & 33 \\
\hline Papua & 6 & 2 & 1 & 20 & 9 & 38 \\
\hline Total & 12 & 9 & 11 & 25 & 14 & 71 \\
\hline
\end{tabular}

used to develop early REDD+ policy recommendations in one province of Indonesia (Purnomo et al. 2012) and is recommended as a tool for managing tropical forest landscapes (van Noordwijk et al. 2013). However, there are no examples of stakeholder analysis being applied for the purpose of analyzing multiple discourses around a policy idea such as REDD+.

\section{METHODS}

As indicated, we adopted a hybrid methodological approach that melded discourse analysis with stakeholder analysis. Actor discourses are usually garnered from sources such as texts and oral transcripts (Hajer 1995). However, few of the subnational actors that we were interested in had expressed relevant views in such a format, meaning that we needed to generate material from scratch. Furthermore, we wanted our target actors to respond to a set of core questions about REDD+ in a pseudo-public setting, where their stances, interactions, and discursive strategies could be observed by us and other stakeholders. We therefore adopted a workshop format for data collection, based on stakeholder analysis methods. This provided a systematic way to bring actors together so that their opinions on REDD+ and forest management could be shared and recorded. Such policy-oriented workshops are common in Indonesia, so our approach was considered locally appropriate.

The initial identification and grouping of stakeholders was a key aspect of workshop preparation. This was achieved through a desktop study of actors associated with forest use in the focal provinces of Riau and Papua, a scoping trip to Riau, a range of key informant interviews (e.g., with informants at Tropenbos, the Centre for International Forestry Research, the Forestry Research and Development Agency, the Ministry of Forestry, and the Ministry of Agriculture [Estate Crops], based variously in Pekanbaru, Bogor, and Jakarta), and several lengthy meetings with Indonesian collaborators. As a result, we defined five stakeholder groups around which the workshops were organized: (1) community members living near forests, and related advocacy or social development nongovernmental organizations (NGOs); (2) companies involved in logging, pulp and paper, and oil palm industries; (3) district government officials; (4) provincial government officials; and (5) environmental NGOs and researchers. National and international actors that did not have an ongoing presence in each province, such as donors, were considered beyond the scope of our analysis. Notably, the stakeholder groupings were useful for organizing data collection, but they did not underpin analysis. This is because our focus on discourses allowed for diverse views and perspectives within stakeholder groups, as well as potential alliances across groups (Gray et al. 2007, Dryzek and Niemeyer 2008). Future workshops may therefore use different stakeholder groupings, depending on the context.

The workshops were held in Riau and Papua: two provinces that represent opposite ends of the spectrum in terms of forest exploitation and land use. In choosing these provinces, our intention was to gauge how contrasting scenarios might shape local perceptions of REDD+. Riau province was selected because it had the highest local deforestation rate in Indonesia in the last decade, with $60 \%$ of its forests removed in the period from $1997-$ 2007 (Gelling 2007). Indeed, emissions from deforestation in Riau accounted for $42 \%$ of Indonesia's national total from 2000-2005 (DNPI 2010b). The province is now largely deforested, with most of its area under concessions for palm oil and acacia (Santosa et al. 2012). Nevertheless, there is a case for REDD+ in Riau because almost all remaining forestland is on peat soils, the burning of which generates disproportionately large carbon emissions (Gaveau et al. 2013).

In contrast, Papua province holds some of Indonesia's largest areas of intact tropical forest, and its forestry and plantation sectors are still in their infancy. The forest is state owned, but subject to customary claims. Forest loss due to logging and local land use in Papua remains relatively low, given sparse human populations and rugged terrain, but forest conversion for industrial plantations now represents a major threat (FPP 2011, Ginting and Pye 2011). As a consequence, the case for REDD+ in Papua relies on protection of its primary forests, to be achieved by averting large-scale planned deforestation. The former governor of West Papua demonstrated exemplary leadership in this domain, winning him the Time Magazine Heroes of the Environment award in 2007 (Tedjasukmana 2007).

Following the desktop study, representatives from each stakeholder group were invited to one-day workshops held in the provincial capitals of Riau and Papua in April and July 2010, respectively (Table 1). Invitations were arranged by the Forestry Research and Development Agency of Indonesia (FORDA), which made it possible to achieve strong attendance by government and business stakeholders, and created an official environment in which stakeholders might be compelled to express their views more seriously than in other settings. This more powerladen context may also have unnerved community-level participants, although such a dynamic was not observed. Funding was provided for some community and district-level representatives to attend from more remote areas (including Rokan Hilir and Siak districts in Riau, and Merauke and Sarmi districts in Papua). Attendance was therefore balanced across all stakeholder groups, but there might have been a degree of provincial capital bias because of the workshop locations. 
Table 2. Questions asked during stakeholder group discussions.

\begin{tabular}{ll}
\hline \hline Category & Question \\
\hline Interests in forests & What is your interest in the forests in Riau? \\
& What role have you played in past and current efforts to manage these forests? \\
& Do you think these efforts have been successful? Why? \\
Interests in REDD ${ }^{\dagger}$ & What does REDD mean to you? \\
& What is your interest in REDD? \\
& What is your current involvement in REDD activities? \\
Perceived costs and benefits of REDD & What gains, benefits, and opportunities do you foresee from REDD? \\
& What costs, losses, and risks do you foresee from REDD? \\
& Overall, do you expect more benefits or costs from REDD? \\
Stakeholder relationships & Who are your stakeholders with respect to your current land use activities and options? \\
& Who would be your key stakeholders under REDD? \\
\hline${ }^{\dagger}$ Reducing emissions from deforestation and forest degradation.
\end{tabular}

The composition of stakeholder groups was also diverse, containing a mix of individual views and roles. For example, government participants in both provinces came from a range of relevant agencies, including the departments of Forestry, Environment, and Estate Crops and Planning. In addition, stakeholder groups varied between provinces because of the provinces' contrasting circumstances. For instance, NGO participants in Riau were predominantly from local advocacy organizations working with communities on resource rights and livelihoods, whereas in Papua, NGO participants generally came from international conservation organizations working more closely with government.

The workshops, held entirely in Indonesian, initially involved plenary sessions on REDD+ delivered by government representatives, including the director of FORDA's REDD+ program. Participants were then divided into their stakeholder groups for roundtable discussions, run in parallel. Each stakeholder group was asked to respond to the same discussion questions, which were crafted to ensure open-ended responses (Table 2). Individual responses from group members were written on cards, and collated group responses were summarized on flip charts, which were later presented by group representatives in a wrap-up plenary session. In addition, most discussion groups were recorded and transcribed. All of these data (response cards, flip charts, transcripts) were then translated from Indonesian into English and entered into NVivo software (QSR International, Melbourne, Australia) for coding and analysis.

Although effective in many ways, the use of stakeholder workshops for data collection does present some methodological issues. For example, to maximize our chances of capturing local voices, we chose to use locally hired facilitators. This was a challenge because of low capacity at the provincial level, but eventually we found sufficiently skilled and informed facilitators from local universities, government departments, and NGOs. The facilitators were briefed on the purpose of the workshops and their role in data collection, but some were not entirely neutral in their stance toward forest management issues and REDD+, which at times affected group discussions. As far as possible, we accounted for this as others have done in similar situations (e.g., Mansbridge et al. 2006). Another potential weakness lies in the selection of representatives to speak on behalf of diverse others such as local communities. Given our aim of capturing a broad overview of local voices, this sampling strategy was deemed legitimate. However, more detailed data on local discourses, and their variable deployment within groups, might be worth pursuing with additional field research or the application of $\mathrm{Q}$ methodology (e.g., Schneider et al. 2015).

In addition, at the time of the workshops, Indonesia's REDD+ policy was still being formulated. Workshop participants were therefore asked to provide views based on their understanding of the REDD+ concept, rather than any particular experience of REDD + in practice. This is another point where our method departed from conventional stakeholder analysis, which tends to be site or project specific (Hjortsø et al. 2005, Mushove and Vogel 2005). Given ongoing uncertainties around REDD+ design internationally, and in Indonesia, the views expressed in our workshops may well change over time. However, our data remain highly relevant for anticipated policy processes; indeed, in April 2015, the Indonesian government reiterated its commitment to REDD+, after a period of doubt and transition (Parlina 2015).

Regarding data analysis, we chose to focus on discourses because we found that the views of each stakeholder group were not unified, although some perspectives were common across multiple groups. Identifying discrete storylines or narratives in the data revealed how forest management and REDD+ are treated discursively by actors (Hajer 1995). In turn, by focusing on discourses, we could determine when one stakeholder group used more than one discourse, and when one discourse was used by multiple stakeholder groups. Notably, it was only with iterative coding of the data that discrete discourses became visible; workshop participants were not engaged in this process. Discourse identification and attribution was also aided by examining key discursive tropes within the data. For example, we observed how group members expressed their "perceptions and concerns for the environment... and [related] external interventions" (Adger et al. 2001:685). We also tried to identify struggles between actors, as manifested through their different framings of environmental disputes, risks, themselves, and their opponents (Wittmer and Birner 2005, Gray et al. 2007). Accordingly, this entailed examining how stakeholders constructed their identities and relationships to each other, especially through use of stereotypes and naming-and-blaming strategies.

Finally, our analytical approach drew from the work of Dryzek and Niemeyer (2008), who argue that deliberative processes should represent different discourses as well as different people 
Table 3. Summary of local discourses and how they were used by stakeholders.

\begin{tabular}{|c|c|c|c|c|c|c|}
\hline \multirow[b]{2}{*}{ Characteristic } & \multicolumn{6}{|c|}{ Discourse } \\
\hline & Environmental & $\begin{array}{l}\text { Sustainable } \\
\text { development }\end{array}$ & $\begin{array}{l}\text { Compliance and } \\
\text { regulation }\end{array}$ & $\begin{array}{l}\text { Community rights } \\
\text { and benefits }\end{array}$ & Developmentalist & Southernism \\
\hline \multicolumn{7}{|c|}{ Position on forest management } \\
\hline & $\begin{array}{l}\text { Ecological } \\
\text { sustainability and } \\
\text { biodiversity } \\
\text { conservation are } \\
\text { vital; these goals can } \\
\text { be achieved through } \\
\text { enforcement of forest } \\
\text { and environment laws }\end{array}$ & $\begin{array}{l}\text { Economic, social, } \\
\text { and environmental } \\
\text { benefits can be } \\
\text { produced through a } \\
\text { balanced and } \\
\text { collaborative strategy } \\
\text { of exploitation and } \\
\text { conservation of } \\
\text { forests }\end{array}$ & $\begin{array}{l}\text { Clear forestry } \\
\text { regulations and } \\
\text { compliance with } \\
\mathrm{SFM}^{\dagger} \text { and } \mathrm{HCVF}^{\star} \\
\text { guidelines are } \\
\text { sufficient to protect } \\
\text { and sustain forests }\end{array}$ & $\begin{array}{l}\text { Recognition of } \\
\text { traditional and local } \\
\text { communities' rights } \\
\text { to forests is essential; } \\
\text { economic benefits } \\
\text { from forest use } \\
\text { should flow to } \\
\text { communities }\end{array}$ & $\begin{array}{l}\text { Economic growth, } \\
\text { welfare, and } \\
\text { development are } \\
\text { priorities; these can } \\
\text { be achieved through } \\
\text { exploitation or } \\
\text { conversion of forests, } \\
\text { before environmental } \\
\text { action }\end{array}$ & $\begin{array}{l}\text { The industrialized } \\
\text { world is responsible for } \\
\text { historical deforestation } \\
\text { and emissions; poor } \\
\text { countries should not } \\
\text { have to curb their } \\
\text { forest use to } \\
\text { compensate }\end{array}$ \\
\hline \multicolumn{7}{|l|}{ Stakeholders: } \\
\hline \multicolumn{7}{|l|}{ Business } \\
\hline & & Papua, Riau & Papua, Riau & Papua, Riau & Papua, Riau & Papua, Riau \\
\hline \multicolumn{7}{|c|}{ Provincial government } \\
\hline & Papua & Papua, Riau & Papua & Papua, Riau & Papua, Riau & Papua, Riau \\
\hline \multicolumn{7}{|c|}{ District government } \\
\hline & Riau & Riau & Papua, Riau & Riau & Riau & Riau \\
\hline \multicolumn{7}{|c|}{ Community and social $\mathrm{NGOs}^{\S}$} \\
\hline & Riau & Papua & & Papua, Riau & Papua, Riau & Riau \\
\hline \multicolumn{7}{|c|}{ Environmental NGOs ${ }^{\S}$} \\
\hline & Papua, Riau & Riau & & & & \\
\hline \multicolumn{7}{|c|}{ Self-representation } \\
\hline & $\begin{array}{l}\text { Environmentalists } \\
\text { and sustainable-forest } \\
\text { managers }\end{array}$ & $\begin{array}{l}\text { Sustainable-forest } \\
\text { managers }\end{array}$ & $\begin{array}{l}\text { Law-abiding and } \\
\text { environmentally } \\
\text { conscious citizens } \\
\text { that undertake SFM } \\
\text { and } \mathrm{HCVF}^{+} \text {in } \\
\text { compliance with the } \\
\text { law }\end{array}$ & $\begin{array}{l}\text { Defenders of } \\
\text { community rights } \\
\text { and benefits; stewards }\end{array}$ & $\begin{array}{l}\text { Providers of regional } \\
\text { economic benefits }\end{array}$ & $\begin{array}{l}\text { Victims of developed } \\
\text { countries' activities }\end{array}$ \\
\hline \multicolumn{7}{|c|}{ Positioning of opponents } \\
\hline & $\begin{array}{l}\text { Overexploitation is } \\
\text { by developers, local } \\
\text { communities, and } \\
\text { concessionaires; } \\
\text { government has low } \\
\text { capacity to regulate } \\
\text { or control } \\
\text { exploitation }\end{array}$ & $\begin{array}{l}\text { Those who } \\
\text { overexploited the } \\
\text { forest in the past and } \\
\text { those who continue, } \\
\text { such as local } \\
\text { communities and } \\
\text { some companies }\end{array}$ & $\begin{array}{l}\text { Weak law } \\
\text { enforcement by } \\
\text { government; } \\
\text { community } \\
\text { encroachment that } \\
\text { undermines corporate } \\
\text { environmental } \\
\text { management }\end{array}$ & $\begin{array}{l}\text { Businesses and } \\
\text { government not } \\
\text { acknowledging } \\
\text { community rights or } \\
\text { providing financial } \\
\text { benefits }\end{array}$ & $\begin{array}{l}\text { Supporters of forest } \\
\text { conservation are } \\
\text { standing in the way } \\
\text { of progress and } \\
\text { regional growth }\end{array}$ & $\begin{array}{l}\text { Developing countries } \\
\text { have overexploited } \\
\text { their own natural } \\
\text { resources }\end{array}$ \\
\hline \multicolumn{7}{|c|}{$\begin{array}{l}\text { Sustainable forest management. } \\
{ }^{+} \text {High conservation value forest. } \\
\text { \$ Nongovernmental organizations. }\end{array}$} \\
\hline
\end{tabular}

or groups. To achieve discursive representation and to aid communication with wider audiences, Dryzek and Niemeyer (2008) suggest that it is possible to map empirically identified discourses onto established or historical discourses in the literature. Following this, we matched discourses found in the workshop data with elements of those identified elsewhere, including global environmental and sustainable development discourses (Dryzek 1997, Adger et al. 2001, Adams 2009), the ecological modernization discourse (Hajer 1995, Bäckstrand and Lövbrand 2006), and discourses on economic growth and developmentalism in the context of environmental conflicts (Gray et al. 2007, Adams 2009). Although the matching was not perfect, the level of correspondence between these global discourses and those we found at the local level is remarkable, especially because some scholars question whether or how discourses apply across scales (Adger et al. 2001). We return to this point in the Discussion. Next, we explain the discourses we identified, along with their implications.

\section{RESULTS: LOCAL DISCOURSES ABOUT FOREST MANAGEMENT AND REDD+}

Despite investigating contrasting regions of Indonesia, we show how subnational actors share similar discourses on forest management and REDD+, as well as similar discursive alliances and conflicts. This common ground may relate to actors' collective exposure to forest-related debates in the media or through environmental projects that transmit so-called global ideas. Overall, we identify six emerging discourses used by local actors, which we labeled as follows: environmental, sustainable development, compliance and regulation, community rights and benefits, developmentalist, and southernism. We define and illustrate each of these, showing how each stakeholder group employs multiple discourses (Table 3 ). We also identify the policy positions on REDD+ reflected by each discourse. Implicitly, each discourse implies a different understanding of forests and sustainability, but we do not unpack stakeholder views of these terms here. 
Before discussing the six discourses, there are some general findings of note. First is the emergence of two broad discursive groupings, which appear to be polarized in their view of REDD+. The first four discourses may generally be considered as pro-forests, with proponents being conditionally supportive of REDD+. However, the latter two discourses, developmentalist and southernism, were more pro-development and less supportive of REDD+. Second, although most stakeholders appeared to understand the basic concept of REDD+ as a market mechanism for forest conservation, none of them expressed their views using an economic rationalist or neoliberal discourse, which would propose "solving environmental problems through the market" (Adams 2009); nor indeed was there evidence of any anti-market sentiment, which sometimes underpins local resistance to REDD+ (Kühne 2012). Instead, most participants focused on governance issues that they thought needed to be addressed before or during REDD+ implementation, such as conflicting laws, government corruption, and insecure resource tenure. In this sense, those who offered conditional support for REDD+ appeared to see it mainly as a way to advance their own agendas.

\section{Environmental discourse}

The environmental discourse values and prioritizes ecological outcomes above all else (Adger et al. 2001). Elements of this discourse were used by district and provincial government officials, particularly those in the Environment department; communities directly affected by deforestation; environmental NGOs; and even business actors. Proponents emphasized that current forest-use practices were adversely affecting ecosystems and villagers. For example, community representatives in Riau said that deforestation had led to "floods and tigers coming into the village." Correspondingly, the discourse implied that forests, still rich in biodiversity, need to be better looked after.

The environmental discourse also featured prominently in actors' discursive strategies. For example, community members and environmental NGOs blamed developers and concessionaires for the high rates of deforestation and biodiversity loss they saw, especially in Riau. This position was adopted by some government officials too, although more often they joined with business representatives to target and blame communities for environmental degradation, despite evidence to the contrary (e.g., Santosa et al. 2012). For example, one district official in Riau argued, "There is still a problem of the community destroying the forest," and, "Whenever there's a jungle, the community just wants to cut it down or plant coconut trees." Similarly, plantation and forestry concession holders claimed that encroachment by local communities into their areas was a major constraint in their efforts to promote better environmental management. In their narrative, the government was also to blame for failing to control illegal forestry activities.

Overall, the environmental discourse supported REDD+ as a way to improve forest management, reduce emissions, and protect ecosystems. Environmental NGOs in particular positioned themselves to "take advantage of REDD+ so that they could implement conservation in any way possible" (Riau-based NGO). The advantage of REDD+ was therefore framed in terms of environmental benefits, rather than potential financial benefits, as some pro-forest Papuan Government officials pointed out. However, the preferred forest policy option in this discourse was generally to encourage sustainable use of forest resources. Consequently, this discourse did not coincide entirely with neoprotectionist or eco-imperialist environmental narratives that suggest the "locking up" of forest under REDD+ (Fairhead et al. 2012).

\section{Sustainable development discourse}

The sustainable development discourse is characterized by the notion of win-win scenarios in which trade-offs between environmental and developmental goals are not necessarily required (Dryzek 1997). Perhaps because of its capacity for accommodating diverse interests, this discourse featured in the language of all stakeholder groups, although with differentiation between provinces. Many proponents of this discourse, especially government officials and environmental NGOs in Riau, positioned themselves by pointing out how past exploitation had "destroyed the forest," and that "timber was just taken for economic return, in an unsustainable way." Thus, they advocated for sustainable forest management that would "account for the destruction that happens" in the course of development. This type of narrative was also prominent among government officials in Papua, who may have been influenced by their pro-REDD+ provincial governor and global conservation NGOs, both active in the province at the time. For example, they argued for a "better balance" between forest preservation and exploitation. However, this line was tempered by an unwillingness to sacrifice the potential economic development to be gained from forests. As one provincial official said, "Basically, we keep on developing, but the environment is still maintained well." Thus, the sustainable development discourse provided them with a way to show awareness of the value of forests while placing an emphasis on local development needs.

Logging and plantation company representatives also adopted this type of position by portraying themselves as environmentally and socially responsible. For example, some of them claimed to be implementing participatory partnerships with communities and environmental management practices that were achieving "sustainable results." Government officials in turn echoed this industry position; some of them maintained that concession management practices were now more sustainable because of training for company staff on sustainable development by Forest and Environment department staff. In keeping with this narrative, all proponents of the sustainable development discourse continued to call for better collaboration between communities, government officials, and companies to improve forest management.

Not surprisingly, the sustainable development discourse clearly recognized REDD + for its potential financial and environmental benefits, as though it were a win-win scenario. For example, some company representatives thought that REDD+ could enable them meet both their profit-making and sustainability objectives through the allocation of concessions to achieve both timber and carbon production. Indeed, the Papuan provincial director of Forestry argued to "utilise REDD+ for sustainable development," and deploy it to "boost the region's development through better forest management that would also increase government revenue." Thus, REDD+ was embraced rather uncritically as a tool to achieve both environmental and developmental outcomes, especially for private and state interests. 


\section{Compliance and regulation discourse}

The compliance and regulation discourse belongs to wider narratives of ecological modernization, a key element of which proposes that technical-institutional "fixes" can provide solutions to environmental problems (Hajer 1995). By implication, there is an anti-politics to this discourse whereby powerful actors seek to avoid confrontation and maintain their interests through the "rendering technical" of forest-related problems ( $\mathrm{Li}$ 2007). This discourse was used during the workshops to frame forest management issues in techno-regulatory terms only, and it was deployed almost exclusively by representatives from the forestry and plantation industries. For instance, they depicted the legal system as a "trusted institution" that should determine who has rights over forested land and who should enforce laws for forest protection. Their discourse hinged on the premise that, if government officials could only formulate clear regulations for achieving environmental objectives, then businesses would simply comply. Frequent reference was also made to regulatory tools and certification schemes as the perfect tools for forest management.

Accordingly, business representatives in Papua and Riau depicted themselves as law-abiding citizens who had contributed to forest security and sustainability through their compliance with relevant laws and regulations. For example, business actors in Papua discussed their legal compliance in terms of the delivery of fees or royalty payments to government and traditional communities, with one logging representative saying, "Here, logging companies are still under control, under the laws and regulations of government... Our role is to implement these rules as best as we can because logging concessions work based on regulation... Another thing is our payment of compensation to customary users... This way, companies contribute to the community and fulfil the Governor's Decree on recognizing customary rights."

In keeping with this line, business participants in Papua blamed illegal loggers for deforestation problems, noting, "Although we try to keep the forest, and the community too, illegal loggers will still try to get in... in any way they can." Thus, Papuan business actors attempted to hide behind the law, accepting no responsibility for noncompliant behavior in their domains. Similarly, in Riau, logging and timber companies portrayed themselves as highly regulated organizations that were now focused on compliance with international standards. For them, this entailed Sustainable Forest Management (SFM) certification and the setting aside of "high conservation value forests" around palm oil plantations.

Another way that concessionaires used the compliance and regulation discourse to deflect potential blame was to criticize government. For example, the national government was blamed for its inability to manage forests and its inadequate law making, especially with regard to land-use planning. As one company representative in Riau explained, "Frankly speaking, regulations in forestry are still inadequate. Many laws and regulations in our country were carelessly made..." A specific legal issue, raised repeatedly, was the government's inability to manage conflicts between communities and concession holders. Company representatives blamed the Forest department, maintaining that it should enforce appropriate laws to achieve environmental and social objectives. For example, one pulp and paper company spokesman in Riau acknowledged that legally they should allocate part of their concession to a "community-company partnership," but he questioned whether companies actually did this in practice because the government was not monitoring the situation. Interestingly, this theme was also picked up by local government staff, mainly district-level forestry officials, who criticized the central government for not providing them with a sufficient operating budget. For this reason, they said they lacked resources to conduct patrols, inspections, and community outreach, as required by law.

Finally, this discourse projected a distinctly pro-business take on REDD+. REDD+ was viewed chiefly as a mechanism to compensate or incentivize businesses for their implementation of SFM practices or other certification schemes. Similarly, those involved in oil palm argued that their actions to comply with the Roundtable on Sustainable Palm Oil guidelines should also attract REDD+ payments. Thus, REDD+ was framed as a potentially beneficial add-on to current business-as-usual scenarios. As one Riau company member said, "Whether we are in forestry or plantations, our true objective is to apply sustainable management. REDD+ is an additional incentive that we can benefit from... Even without the REDD+ mechanism, we have applied SFM certification..." This argument was also extended to companies' compliance with domestic legal frameworks. As one logging representative said in Papua, REDD+ could benefit everyone "if only the regulations were clear and targeted." Thus, the government was made responsible for legal-regulatory improvements, which were framed as a prerequisite for REDD+.

\section{Community rights and benefits discourse}

The community rights and benefits discourse resonates with socalled eco-populist discourses whereby resource-dependent villagers are understood as victims of change, forced to abandon their environmentally benign land-use traditions (Adger et al. 2001, Adams 2009). This discourse was used by all stakeholder groups to varying degrees, but it primarily belonged to community representatives and social development NGOs. It portrayed indigenous and local communities as the rightful owners and managers of forests, which they depend on for their identity and livelihoods. For example, indigenous representatives in Papua explained the significance of forests to their lives: "The most important thing for the people of Papua is customary rights... Almost $90 \%$ of the traditional community around the forest is dependent on the forest... It is the source of life for the community." Similarly, in Riau, local NGOs and community members argued that forests had historically been an integral part of village livelihoods, but that over time, forest ownership had shifted to companies and the government. This had caused, according to one NGO, a "separation of society from its cultural roots" along with the loss of traditional livelihoods.

A strong feature of this discourse was that community and NGO representatives portrayed customary forest users as victims of powerful forces such as logging and plantation interests. They especially argued that companies had disregarded customary user rights and were destroying the forest. For example, one community representative in Papua referred to new investors in Merauke district who "do not respect our map... and are taking apart our forest." In addition, "economic pressures" were blamed for forcing communities to abandon their traditional forest management systems to provide for their families. As one 
community representative from Papua said, "In the past, local knowledge about forest management was held in high esteem and respected by parties managing the forest, including the community. Local knowledge is less respected now..."

However, in Riau, where dispossession and deforestation are far more advanced, community members argued that companies should compensate them for their lost livelihoods or at least share the benefits of forest exploitation. As one local representative said, "If the logging company keeps on exploiting our forest without doing anything for the community, we will be at a loss, just watching and not getting anything until it's gone... It's a responsibility of the company to give benefits back to us... but the company has given nothing." Community representatives of this inclination, predominantly those in Riau, were not necessarily interested in protecting the forest for future generations or for cultural reasons. For example, when Riau community leaders were asked what they would do with the company's land if they could acquire it, some responded that they would "turn it into a plantation."

Thus, the community rights and benefits discourse does not always idealize traditional or indigenous livelihoods. Rather, it prioritizes the needs and rights of people living in and around forests, emphasizing that they should be beneficiaries of forest management and exploitation. To this end, community participants called for customary user rights in new concession areas to be recognized formally, especially through royalty payments to communities. This argument had special significance in Papua, where customary ownership of forests is the norm. Government participants there, themselves of Papuan origin, criticized Indonesian national regulations for being too general and for not addressing the specific concerns of Papua. This, they argued, impeded their ability to secure benefits for communities from forest use.

Proponents of this discourse said they would only support REDD + if it were based upon clear recognition of customary rights and direct financial incentives to local communities. They strongly emphasized local rights, arguing that communities as "actors in and owners of the forest" should be involved in REDD+ "from planning through to implementation." In Riau, this argument was taken one step further by local advocacy NGOs, who saw REDD+ as an opportunity to reinstate community rights, arguing, "REDD+ is not just about compensation, but also how to restore the rights of the community. Communities need legal recognition. Even if REDD+ does not happen, communities must understand that the forest is their right..." Interestingly, this rights-based language was also used by business representatives in Papua, who from their own experience saw recognition of community rights and associated royalties as a way to avoid local conflict, with one of them saying, "if communities don't have rights or benefits, then REDD+ will be useless."

Finally, all of these assertions were made in the context of community participants' own acknowledgment of their lack of knowledge on REDD+. In Papua, they likened REDD+ to a "foreign language" heard only in government offices. In Riau, communities said that they did not understand "the meaning" of REDD+. Thus, the discourse also entailed doubts and concerns about the prospect of achieving community rights through REDD+, especially given current weak tenure arrangements. This caused some people to warn that REDD+ benefits would probably go to companies and the forest department, in keeping with the status quo: "The community gets nothing. It's only the forestry staff and companies enjoying the benefits... That's what we're afraid of again... we want at least $50 \%$ of the profit given back to surrounding communities..." (Riau-based NGO). This was just one of many calls for REDD+ benefits to reach communities.

\section{Developmentalist discourse}

In the developmentalist discourse, economic growth and poverty alleviation are seen as priorities to be achieved before environmental action (Wittmer and Birner 2005). For the Indonesian context, this discourse posited that forest exploitation and conversion were the most valuable land uses for the growing population. Proponents saw forests and plantations as key sources of income for individuals, their districts, and the nation. This idea was particularly espoused by government officials, who positioned themselves as forest managers and owners. As one government representative in Papua put it, "Forests are a national and local government asset to support development."

Business representatives also deployed the developmentalist discourse, portraying themselves as economic actors who were contributing to regional growth through forest exploitation. For example, logging and plantation companies in Papua argued that their activities were creating new roads, new jobs, and even new municipalities. In this way, they positioned themselves apolitically as benevolent developers, saying, "Our activities give... pride to business people, as we help to open new areas [for development]." In this discussion, companies in Papua noted strong government "pressure to form new regions" at the forest frontier through the creation of new administrative districts. This government-led agenda is known to serve a range of elite interests in Indonesia (Luttrell et al. 2014).

Given the emphasis on economic growth through resource exploitation, it is not surprising that this discourse was distinctly anti-conservation. For example, forest conservation was alleged to be in direct conflict with regional development plans, including the expansion of industries and population growth. This was particularly emphasized in underdeveloped Papua, where one provincial government official maintained, "Preserving the forest is inversely related to development."

Correspondingly, proponents of this discourse did not support REDD+, especially in the business and provincial government stakeholder groups. These actors raised concerns about the potentially negative effects of REDD+ on forest-related industries, regional employment, and economic expansion. For example, one official in Riau argued, "If REDD+ is applied to productive forests... some industries might close." Likewise, one business actor in the same province claimed provocatively that if REDD+ was implemented widely, "The timber industry will shut down, as well as the plywood industry, chip mills, saw mills, and so on... it may lead to massive unemployment... and social conflict." This type of narrative was used repeatedly by the key beneficiaries of forest exploitation, who emphasized that REDD+ would be a "lost opportunity for development." They even speculated about the effects of REDD+ on communities, asking rhetorically, "How about the communities' right to development, such as roads, schools, urban areas, health, 
transport? Is the government ready to take responsibility for that?" Thus, the discursive strategy of these elite actors was to portray REDD+ supporters as anti-development and anticommunity rights, while defending their own interests.

\section{Southernism discourse}

The last discourse to emerge was that of southernism. This discourse is an element of broader populist and environmental justice narratives identified in the global context (Adger et al. 2001). Proponents typically blame the industrialized world for past deforestation and carbon emissions, leading to today's climate problem. Forest-rich developing countries are therefore depicted as victims of the developed North, with a right to call on them to "clean up their own back yards" before transferring responsibility onto less-developed others (Adger et al. 2001). This discourse is clearly evident in the context of REDD+ in Indonesia, with some government representatives calling on industrialized countries to provide compensation for the fact that Indonesia's forests "help the world to absorb carbon" (Cronin and Santoso 2010:10).

At the workshops, the southernism discourse was used by government and business representatives to support their prodevelopment stance and to oppose REDD+. They depicted REDD+ as a strategy devised by developed countries to exploit poorer forest-rich nations, or as a way for them to avoid responsibility for climate change while underhandedly making less developed countries worse off. Government participants in Riau were particularly vocal in this way. They argued, "It is unfair [of developed countries]... to put pressure on us over forest destruction... this problem began in their countries and they should be responsible for that." Along these lines, some workshop participants perceived REDD+ as a mechanism that would benefit developed countries far more than it would poor countries such as Indonesia. For example, one district official in Riau argued, "They give donations, like REDD $+\ldots$ but we really want to know if they intend to help us. There's a possibility that [they will] get more benefits than what they give to us... and we will suffer."

Similar arguments were made in Papua, where one business representative said that their forests were becoming viewed as "the lung" for developed countries to benefit from, asking, "Is it fair for countries with vast forests to take responsibility for global warming, while industrialized countries get off the hook?" Indeed, this view is a key challenge to the feasibility of REDD+ globally, as evidenced in UNFCCC negotiations in which the issue of North-South equity has been hotly contested (Baer et al. 2000). Southernism, in general, is therefore more anti-colonial than antienvironment.

\section{DISCUSSION}

\section{New policy, old discourses?}

While local understandings of REDD+ were rudimentary at the time of the workshops, it is notable how much people had to say on the subject. This is because the idea of REDD+ necessarily mobilizes and is discussed in terms of pre-existing discourses on forest management and environment-development issues. REDD+ discourses therefore did not exist in their own right, but were a subset or extension of the underlying discursive realm. Given this, REDD+ has the potential to become a new prop in an old game or an empty signifier that local actors intuitively fill with meanings that perpetuate their already-held narratives and ideas, as our analysis suggests.

This finding implies that subnational actors will most likely endeavor to use REDD+ as a way to serve their existing objectives and interests, rather than seeing it as a fresh solution to forest governance problems or as a new set of rules. Given the obvious unresolved conflicts in Indonesia's forest sector, the risk then is that REDD+ in practice will simply reproduce existing struggles and inequalities between communities, companies, and the state, or indeed exacerbate them, as recent observations of Kalimantan suggest (Eilenberg 2015). For this reason, questions about REDD+ policy formulation have rightly focused on its transformative potential (Gallemore et al. 2014, Moeliono et al. 2014). However, as we have shown, these inquiries are incomplete without consideration of the multiplicity of discourses at the local level and how this might affect policy implementation.

Another key dimension in local-level REDD+ is the cross-scalar circulation of discourses and ideas. Having discovered strong resonances between local discourses and pre-established global discourses, as well as similar discursive patterns emerging from two very different field settings, this matter requires further research. However, we suggest two factors that may have influenced our findings. First, most workshop participants would have been exposed to global environmental discourses through the media and through their roles in forest management and related international projects. This, we propose, would have influenced their (re)articulation of ideas and discursive strategies, resulting in the cross-scalar resonances we observed. Second, the workshops were transnational events, given their focus on international policy and the presence of foreign researchers and national-level REDD+ specialists. In this context, workshop participants may have been inclined to communicate in globally legible ways, perhaps by deploying elements of well-established global discourses strategically to legitimize their arguments. The workshops' transnational character may also have restricted space for subaltern perspectives in the discussion, particularly indigenous and community voices. These dynamics signal, again, the need for REDD+ implementation to attend to local nuances if conflict and miscommunication are to be avoided (Howell 2015).

\section{Discourse coalitions to shape policy outcomes?}

Our findings also suggest that, for REDD+ to be implementable, there is a strong need for local actors to establish common forest management goals. Analytically, this implies the formation of discourse coalitions, which emerge with the convergence of different actors' narratives or storylines about environmental problems and how they might be solved (Hajer 1995). As indicated, we identified two emergent discursive groupings around REDD+ and forest management: one group being "prodevelopment and pro-forest exploitation," and the other being "pro-sustainable forest management." These groups have the potential to form discourse coalitions, which in turn may influence policy outcomes.

The pro-development group consists chiefly of arguments and strategic positionings found in the developmentalist and southernism discourses, with some elements of the community rights and benefits discourse. The latter emphasized local 
economic benefits for communities living in and around forests, while the developmentalist discourse focused more on regional or provincial economic benefits, and the southernism discourse appealed to the need for Indonesia to secure financial resources as a developing nation. Thus, the discourses in this group are tied together by their prioritization of economic growth, generally at the expense of forest conservation, but different actors push for benefits to be accrued at different scales. Consequently, there is no clear policy position in this group other than a generalized anti-REDD+ stance.

The pro-sustainable forest management group comprises discursive elements from the environmental, sustainable development, and compliance and regulation discourses, with some aspects of the community rights and benefits discourse. This group believed in and sought a balance of economic, social, and environmental benefits from forests. Their position was that this aim could be achieved through sustainable and collaborative management practices. Interestingly, their storylines converged around criticism of the government, especially in relation to weak forest law enforcement and poor implementation of tenure reforms and land-use plans. Thus, their position on REDD+ depended on central government action in addressing governance issues first.

Conditional support for REDD+ was therefore a key feature of the pro-sustainable forest management group; their interest in REDD+ was motivated by a desire to achieve other objectives, whether social or environmental. For example, advocacy NGOs in the community rights and benefits discourse supported REDD+ so long as it could provide secure property rights and better livelihoods to local communities. In contrast, environmental NGOs supported REDD+ so long as it could contribute to biodiversity conservation. Interestingly, these locally articulated positions correspond with demand for the delivery of co-benefits, which is now a key feature of global REDD+ policy. Just as Howell (2014) has observed in international spheres, securing local support for REDD+ will therefore likely hinge upon co-benefits that can meet diverse stakeholder interests.

Ultimately, the implication of these two divergent groups is that realizing REDD+ on the ground will not be easy, even if the best possible policy design is achieved at national and global levels. Indeed, our results suggest that REDD+ implementation at the subnational level will give rise to discursive and material struggles that reflect underlying forest governance issues. Careful and creative alliance building will therefore be required if REDD+ is to avoid perpetuating or precipitating conflicts, as others imply (Luttrell et al. 2014, Moeliono et al. 2014).

\section{CONCLUSION}

We investigated the voices and perceptions of subnational stakeholders in REDD+ and forest management in Indonesia, with implications for elsewhere. Our study focused on data collected at stakeholder workshops, held in the two contrasting provinces of Riau and Papua. Although we expected to find quite different discourses in each setting, we instead found six discourses common to stakeholders in both provinces, reflecting how the environment-development domain is contested and how discourses can resonate between places or across scales. Critically, this consistent presence of multiple competing discourses signals the key challenge for REDD+: the need to accommodate and resolve contestation that is present not only at the global level but also at the subnational level. Meeting this challenge will ultimately require site-specific problem solving, which our analysis could well assist.

Another important finding is that discourses do not correspond neatly with stakeholder groups, reflecting intragroup diversity. Different actors were also prone to using more than one discourse, depending on the subject matter or audience in question. For example, business actors claimed to be bringing development to Indonesia's rural poor through their investments on the one hand, while blaming local communities for forest destruction on the other. These contradictions present a key limitation of conventional stakeholder analysis, which, in future, might account for discursive representation as well (Dryzek and Niemeyer 2008). Indeed, by analyzing discourses rather than stakeholders, we identified critical struggles and potential actor alliances that may affect REDD+ outcomes.

Finally, we note the strong possibility that REDD+ implementation will simply reproduce or be constituted by preexisting discourses, which are highly contested. REDD+ realization will therefore depend on the formation of favorable alliances or discourse coalitions at the local level, a dynamic and informal process that can be hard to orchestrate (Hajer 1995). In practice, this means that REDD+ will need to appeal to various agendas while also addressing underlying forest governance issues. Herein, practitioners will likely need to address the two discursive groupings that we observed, which exhibited divergent positions on REDD+. Failure to do so could have destabilizing effects. In other words, policy and practice must be grounded in, and able to respond to, local voices and concerns, no matter how diverse. This represents a particular challenge for REDD+, which is, by definition, generic and top-down.

\section{Responses to this article can be read online at: http://www.ecologyandsociety.org/issues/responses. $\mathrm{php} / 8363$}

\begin{abstract}
Acknowledgments:
We thank all the stakeholders who participated in the workshops in Papua and Riau. Research for this paper was supported by funding from the Australian Centre for International Agricultural Research grant (FST/2007/052) "Improving governance, policy and institutional arrangements to reduce emissions from deforestation and degradation (REDD)". The paper also benefited from feedback from colleagues at the ANU, including John Boswell, and three anonymous reviewers.
\end{abstract}

\section{LITERATURE CITED}

Adams, W. M. 2009. Green development: environment and sustainability in a developing world. Third edition. Routledge, London, UK.

Adams, W. M., D. Brockington, J. Dyson, and B. Vira. 2003. Managing tragedies: understanding conflict over common pool resources. Science 302(5652):1915-1916. http://dx.doi.org/10.1126/ science. 1087771 
Adger, W. N., T. A. Benjaminsen, K. Brown, and H. Svarstad. 2001. Advancing a political ecology of global environmental discourses. Development and Change 32(4):681-715. http://dx.doi. org/10.1111/1467-7660.00222

Adger, W. N., K. Brown, J. Fairbrass, A. Jordan, J. Paavola, S. Rosendo, and G. Seyfang. 2003. Governance for sustainability: towards a 'thick' analysis of environmental decisionmaking. Environment and Planning A 35(6):1095-1110. http://dx.doi. org/10.1068/a35289

Bäckstrand, K., and E. Lövbrand. 2006. Planting trees to mitigate climate change: contested discourses of ecological modernization, green governmentality and civic environmentalism. Global Environmental Politics 6(1):50-75. http://dx.doi.org/10.1162/ glep.2006.6.1.50

Baer, P., J. Harte, B. Haya, A. V. Herzog, J. Holdren, N. E. Hultman, D. M. Kammen, R. B. Norgaard, and L. Raymond. 2000. Equity and greenhouse gas responsibility. Science 289 (5488):2287. http://dx.doi.org/10.1126/science.289.5488.2287

Beymer-Farris, B. A., and T. J. Bassett. 2012. The REDD menace: resurgent protectionism in Tanzania's mangrove forests. Global Environmental Change 22(2):332-341. http://dx.doi.org/10.1016/ j.gloenvcha.2011.11.006

Brockhaus, M., M. Di Gregorio, and R. Carmenta (editors). 2014a. REDD+ national policy networks: information flows, influence, and coalitions for change. Ecology and Society SF97. [online] URL: http://www.ecologyandsociety.org/issues/view. php/feature/97

Brockhaus, M., M. Di Gregorio, and R. Carmenta. $2014 b$. REDD+ policy networks: exploring actors and power structures in an emerging policy domain. Ecology and Society 19(4):29. http://dx.doi.org/10.5751/es-07098-190429

Brown, H. C. P., B. Smit, D. J. Sonwa, O. A. Somorin, and J. Nkem. 2011. Institutional perceptions of opportunities and challenges of REDD+ in the Congo basin. Journal of Environment and Development 20(4):381-404. http://dx.doi.org/10.1177/1070$\underline{496511426480}$

Coates, S. 2012. Green group, analysts slam Indonesia logging ban. Agence France Presse, Paris, France. [online] URL: http://www. orangutans.com.au/Orangutans-Survival-Information/Green-groupanalysts-slam-Indonesia-logging-plan.aspx

Cronin, T., and L. Santoso. 2010. REDD+ politics in the media: a case study from Indonesia. Working Paper 49. CIFOR, Bogor, Indonesia. [online] URL: http://www.cifor.org/publications/ pdf files/WPapers/WP-49Santoso.pdf

de Lopez, T. T. 2001. Stakeholder management for conservation projects: a case study of Ream National Park, Cambodia. Environmental Management 28(1):47-60. http://dx.doi.org/10.1007/ $\underline{\mathrm{s} 002670010206}$

DNPI (National Council on Climate Change - Indonesia). 2010a. Indonesia's greenhouse gas abatement cost curve. DNPI, Jakarta, Indonesia. [online] URL: http://www.mmechanisms.org/document/ country/IDN/Indonesia ghg cost curve english.pdf

DNPI (National Council on Climate Change - Indonesia). $2010 b$. Economic incentive policies for REDD+ in Indonesia: findings from OSIRIS model. Policy Memo 2. DNPI, Jakarta, Indonesia. [online] URL: http://theredddesk.org/sites/default/files/resources/ pdf/2011/dnpi policy memo 2 -- economic incentive policiesfor redd in indonesia.pdf

Dryzek, J. S. 1997. The politics of the Earth: environmental discourses. Oxford University Press. Oxford, UK.

Dryzek, J. S., and S. Niemeyer. 2008. Discursive representation. American Political Science Review 102(4):481-493. http://dx.doi. org/10.1017/s0003055408080325

Eilenberg, M. 2015. Shades of green and REDD: local and global contestations over the value of forest versus plantation development on the Indonesian forest frontier. Asia Pacific Viewpoint 56(1):48-61. http://dx.doi.org/10.1111/apv.12084

Entenmann, S. K., and C. B. Schmitt. 2013. Actors' perceptions of forest biodiversity values and policy issues related to REDD+ implementation in Peru. Biodiversity and Conservation 22 (5):1229-1254. http://dx.doi.org/10.1007/s10531-013-0477-5

Evans, K., L. Murphy, and W. de Jong. 2014. Global versus local narratives of REDD: a case study from Peru's Amazon. Environmental Science and Policy 35:98-108. http://dx.doi. org/10.1016/j.envsci.2012.12.013

Fairhead, J., and M. Leach. 2003. Science, society and power: environmental knowledge and policy in West Africa and the Caribbean. Cambridge University Press, Cambridge, UK.

Fairhead, J., M. Leach, and I. Scoones. 2012. Green grabbing: a new appropriation of nature? Journal of Peasant Studies 39 (2):237-261. http://dx.doi.org/10.1080/03066150.2012.671770

FAO (Food and Agriculture Organization). 2010. Global forest resources assessment 2010: main report. FAO Forestry Paper 163. FAO, Rome, Italy. [online] URL: http://www.fao.org/docrep/013/ i1757e/i1757e00.htm

FPP (Forest Peoples Programme). 2011. Papua and West Papua: $R E D D+$ and the threat to indigenous peoples. Rights, forest and climate briefing series - October 2011. Forest Peoples Programme, Moreton-in-Marsh, UK. [online] URL: http://www.forestpeoples. org/sites/fpp/files/publication/2011/10/papua-briefing-6.pdf

Gallemore, C. T., R. Dini Prasti H., and M. Moeliono. 2014. Discursive barriers and cross-scale forest governance in Central Kalimantan, Indoesnia. Ecology and Society 19(2):18. http://dx. doi.org/10.5751/ES-06418-190218

Gaveau, D. L. A., M. A. Salim, K. Hergoualc'h, B. Locatelli, S. Sloan, M. Wooster, M. E. Marlier, E. Molidena, H. Yaen, R. DeFries, L. Verchot, D. Murdiyarso, R. Nasi, P. Holmgren, and D. Sheil. 2013. Major atmospheric emissions from peat fires in Southeast Asia during non-drought years: evidence from the 2013 Sumatran fires. Scientific Reports 4:6112. http://dx.doi. org/10.1038/srep06112

Gelling, P. 2007. Forest loss in Sumatra becomes a global issue. New York Times December 6, A14 [print]. [online] URL: http:// www.nytimes.com/2007/12/06/world/asia/06indo.html?_r=0

Ginting, L., and O. Pye. 2011. Resisting agribusiness development: the Merauke Integrated Food and Energy Estate in West Papua, Indonesia. Institute of Development Studies, University of Sussex, Brighton, UK. [online] URL: http://www.iss.nl/fileadmin/ 
ASSETS/iss/Documents/Conference papers/LDPI/1 Longgena_Ginting_and_Oliver_Pye_Final.pdf

Gray, B., R. C. Hanke, and L. L. Putnam. 2007. The discourse of environmental conflicts: how stakeholders construct their claims, their opponents and themselves. IACM 2007 Meetings Paper. Social Science Research Network, Rochester, New York, USA. http://dx.doi.org/10.2139/ssrn.1111635

Grimble, R., and M.-K. Chan. 1995. Stakeholder analysis for natural resource management in developing countries. Natural Resources Forum 19(2):113-124. http://dx.doi.org/10.1111/ j.1477-8947.1995.tb00599.x

Hajer, M. A. 1995. The politics of environmental discourse: ecological modernization and the policy process. Oxford University Press, Oxford, UK. http://dx.doi.org/10.1093/019829333x.001.0001

Hjortsø, C. N., S. M. Christensen, and P. Tarp. 2005. Rapid stakeholder and conflict assessment for natural resource management using cognitive mapping: the case of Damdoi Forest Enterprise, Vietnam. Agriculture and Human Values 22 (2):149-167. http://dx.doi.org/10.1007/s10460-004-8275-z

Howell, S. 2014. 'No RIGHTS-no REDD': some implications of a turn towards co-benefits. Forum for Development Studies 41 (2):253-272. http://dx.doi.org/10.1080/08039410.2014.901241

Howell, S. 2015. The politics of appearances: some reasons why the UN-REDD project on Central Sulawesi failed to unite the various stakeholders. Asia Pacific Viewpoint 56(1):37-47. http:// dx.doi.org/10.1111/apv.12081

Keeley, J., and I. Scoones. 1999. Understanding environmental policy processes: a review. IDS Working Paper 89. Institute of Development Studies, Brighton, UK. [online] URL: http://www. ids.ac.uk/publication/understanding-environmental-policy-processesa-review

Kühne, K. 2012. REDD resistance around the world. REDD Monitor 14 November 2012. [online] URL: http://www.reddmonitor.org/2012/11/14/guest-post-redd-resistance-around-the-world/

Lang, C. 2013. Almost half of Norway's climate and forest aid remains unspent. REDD Monitor 20 September 2013. [online] URL: http://www.redd-monitor.org/2013/09/20/almost-half-ofnorways-climate-and-forest-aid-remains-unspent/

Leach, M., and R. Mearns, editors. 1996. The lie of the land: challenging received wisdom on the African environment. International African Institute and James Currey, Oxford, UK.

Li, T. M. 2007. The will to improve: governmentality, development, and the practice of politics. Duke University Press, Durham, North Carolina, USA. http://dx.doi.org/10.1215/9780822389781

Luttrell, C., I. A. P. Resosudarmo, E. Muharrom, M. Brockhaus, and F. Seymour. 2014. The political context of REDD+ in Indonesia: constituencies for change. Environmental Science and Policy 35:67-75. http://dx.doi.org/10.1016/j.envsci.2012.10.001

Mahanty, S., A. Bradley, and S. Milne. 2015. The forest carbon commodity chain in Cambodia's voluntary carbon market. Pages 177-199 in S. Milne and S. Mahanty, editors. Conservation and development in Cambodia: exploring froniters of change in nature, state and society. Routledge, Abingdon, UK.
Mansbridge, J., J. Hartz-Karp, M. Amengual, and J. Gastil. 2006. Norms of deliberation: an inductive study. Journal of Public Deliberation 2(1):7 [online] URL: http://www.publicdeliberation. net/jpd/vol2/iss1/art7

McGregor, A. 2010. Green and REDD? Towards a political eoclogy of deforestation in Aceh, Indonesia. Human Geography $3(2): 21-34$.

McGregor, A., M. Eilenberg, and J. Borges Coutinho (editors). 2015. From Global Policy to Local Politics: The Social Dynamics of REDD+ in Asia Pacific. Asia Pacific Viewpoint 56(1):1-187. [online] URL: http://onlinelibrary.wiley.com/doi/10.1111/apv.2015.56. issue-1/issuetoc

Moeliono, M., C. Gallemore, L. Santoso, M. Brockhaus, and M. Di Gregorio. 2014. Information networks and power: confronting the "wicked problem" of REDD+ in Indonesia. Ecology and Society 19(2):9. http://dx.doi.org/10.5751/ES-06300-190209

Mosse, D. 2004. Is good policy unimplementable? Reflections on the ethnography of aid policy and practice. Development and Change 35(4):639-671. http://dx.doi.org/10.1111/j.0012-155x.2004.00374. $\mathrm{x}$

Mulyani, M., and P. Jepson. 2013. REDD+ and forest governance in Indonesia: a multistakeholder study of perceived challenges and opportunities. Journal of Environment and Development 22 (3):261-283. http://dx.doi.org/10.1177/1070496513494203

Mushove, P., and C. Vogel. 2005. Heads or tails? Stakeholder analysis as a tool for conservation area management. Global Environmental Change 15(3):184-198. http://dx.doi.org/10.1016/ j.gloenvcha.2004.12.008

Neumann, R. P. 2005. Making political ecology. Hodder Education, London, UK.

Parlina, I. 2015. RI-Norway agree to continue REDD+. Jakarta Post April 15, page 3 [print]. [online] URL: http://www. thejakartapost.com/news/2015/04/15/ri-norway-agree-continue-redd. html

Phelps, J., E. L. Webb, and A. Agrawal. 2010. Does REDD+ threaten to recentralize forest governance? Science 328 (5976):312-313. http://dx.doi.org/10.1126/science.1187774

Purnomo, H., D. Suyamto, L. Abdullah, and R. H. Irawati. 2012. REDD+ actor analysis and political mapping: an Indonesian case study. International Forestry Review 14(1):74-89. http://dx.doi. org/10.1505/146554812799973208

Roe, E. M. 1991 Development narratives, or making the best of blueprint development. World Development 19(4):287-300. http:// dx.doi.org/10.1016/0305-750X(91)90177-J

Santosa, K., E. Hartoyo, P. Gunarso, A. Dermawan, and K. Obidzinski. 2012. Analysis of land cover change, forest degradation and deforestation in Siak and Rokan Hilir Districts, Riau. CIFOR and Tropenbos, Bogor, Indonesia.

Schneider, C., E. Coudel, F. Cammelli, and P. Sablayrolles. 2015 Small scale farmers' needs to end deforestation: insights for REDD+ in São Felix do Xingu (Pará, Brazil). International Forestry Review 17(S1):124-142. http://dx.doi.org/10.1505/1465$\underline{54815814668963}$ 
Silva-Chávez, G. 2015. New finance commitments for forests build momentum in Paris; much more action needed. Huffington Post November 30. [online] URL: http://www.huffingtonpost. com/gustavo-silvachavez/new-finance-commitments-f_b_ 8684398. $\underline{\mathrm{html}}$

Somorin, O. A., H. C. P. Brown, I. J. Visseren-Hamakers, D. J. Sonwa, B. Arts, and J. Nkem. 2012. The Congo Basin forests in a changing climate: policy discourses on adaptation and mitigation (REDD+). Global Environmental Change 22 (1):288-298. http://dx.doi.org/10.1016/j.gloenvcha.2011.08.001

Tedjasukmana, J. 2007. Heroes of the environment: Barnabas Suebu. Time October 17. [online] URL: http://content.time.com/ time/specials/2007/article/0,28804,1663317_1663319_1669895,00. $\underline{\mathrm{html}}$

UNFCCC (United Nations Framework Convention on Climate Change). 2015. Adoption of the Paris Agreement. UNFCC, Bonn, Germany. [online] URL: http://unfccc.int/resource/docs/2015/ cop21/eng/109r01.pdf

van Noordwijk, M., B. Lusiana, B. Leimona, S. Dewi, and D. Wulandari, editors. 2013. Negotiation-support toolkit for learning landscapes. World Agroforestry Centre (ICRAF) Southeast Asia Regional Program, Bogor, Indonesia. [online] URL: http:// worldagroforestry.org/regions/southeast asia/publications?do= view_pub detail\&pub no=BK0170-13

Wertz-Kanounnikoff, S., and M. Kongphan-Apirak. 2009. Emerging REDD+: a preliminary survey of demonstration and readiness activities. CIFOR Working Paper 46. CIFOR, Bogor, Indonesia. http://dx.doi.org/10.17528/cifor/002869

West, P. 2006. Conservation is our government now: the politics of ecology in Papua New Guinea. Duke University Press, Durham, North Carolina, USA. http://dx.doi.org/10.1215/9780822388067

Wittmer, H., and R. Birner. 2005. Between conservationism, ecopopulism and developmentalism: discourses in biodiversity policy in Thailand and Indonesia. CAPRi Working Paper 37. International Food Policy Research Institute, Washington, D.C., USA. [online] URL: http://hdl.handle.net/10535/3638

Yudhoyono, H. E. S. B. 2009. Indonesia President's speech on climate change at 2009 G-20 meeting. [online] URL: http://www. scribd.com/doc/29583473/Indonesia-President-s-speech-on-climatechange-at-2009-G-20-meeting 